\title{
Shallow-Mush reservoir conditions in the Fui Group small eruptive centres in the Southern Volcanic Zone (Chilean Andes)
}

\author{
FRANCISCA MALLEA-LILLO ${ }^{1,2}$, MIGUEL ÁNGEL \\ PARADA $^{1,2}$, EDUARDO MORGADO ${ }^{2,3}$, CLAUDIO \\ CONTRERAS $^{4}$ AND DARÍO HÜBNER ${ }^{1,2}$ \\ ${ }^{1}$ University of Chile \\ ${ }^{2}$ Andean Geothermal Center of Excellence, CEGA \\ ${ }^{3}$ University of Leeds \\ ${ }^{4}$ University of Bristol \\ Presenting Author: francisca.mallea@ug.uchile.cl
}

The Fui Group are clusters of Holocene Small Eruptive Centres (SECs) located at the east and north-east from the Mocho-Choshuenco Volcanic Complex and along the Liquiñe Ofqui Fault Zone, in the Central Southern Volcanic Zone of the Chilean Andes. We recognised two sets of volcanic products based on geochemical signatures, petrographic features, and geographical position: Fui Norte (north) and Fui Sur (south). The distance between those subgroups is $\sim 2 \mathrm{~km}$. Fui Norte volcanic products are basalts and basaltic andesites $\left(49-52 \mathrm{SiO}_{2} \mathrm{wt} \%\right)$, olivine-rich, relatively enriched in incompatible elements, whilst Fui Sur material are more evolved (basaltic andesites to andesites; $55-58 \mathrm{SiO}_{2} \mathrm{wt} \%$ ) with less amounts of olivines and more plagioclase and clinopyroxene, and relatively depleted in incompatible elements. We classified olivine and plagioclase phenocrysts from both sets based on two compositional zones: Mg-rich, high-Ca (Zone 1) and Mg-poor, low-Ca (Zone 2), respectively. Olivine and plagioclase phenocrysts, together with clinopyroxene, form crystal clots that are abundant in all the studied samples.

We performed thermodynamic modelling via MELTS software and detected shallow reservoir conditions (4.5-7.2 km in Fui Norte and 5.7-8.3 km in Fui Sur) for Zone 2 compositions in equilibrium with groundmass (representing a late stage of melt evolution) composition. Considering the presence of abundant crystal clots in all samples (lavas and pyroclasts), disequilibrium textures such as resorption and zonation, and the growth of euhedral plagioclases, as well as glass, filling the resorbed zones of crystals, we infer that Zone 1 compositions were formed in a melt different from the groundmass composition as an earlier stage of crystallisation in a mushy zone within the reservoir for the two sets of SECs. Based on the relatively low crystallinity of the studied volcanic products (3-20 vol.\%) we infer that extraction and transportation of the fractionated melt to an accumulation zone took part in the reservoir, with a late crystallisation stage, in which grew crystals and rims of Zone 2 composition. 